\title{
The anatomical properties of endemic Hypericum kotschyanum Boiss.
}

\author{
Onur Altınbașak (D), Gülay Ecevit Genç D, Șükran Kültür (D) \\ Istanbul University, Faculty of Pharmacy, Pharmaceutical Botany, Istanbul, Turkey
}

ORCID IDs of the authors: 0.A. 0000-0002-7167-7663; G.E.G. 0000-0002-1441-7427; S.K. 0000-0001-9413-5210

Cite this article as: Altinbasak, O., Ecevit Genc, G., \& Kultur, S. (2021). The anatomical properties of endemic Hypericum kotschyanum Boiss. Istanbul Journal of Pharmacy, 51(1), 133-136.

\begin{abstract}
Background and Aims: This study reveals the anatomical features of Hypericum kotschyanum Boiss. species and compares them with previous studies. The anatomical characteristics of stem, leaf, and root were studied using a light microscope. In addition, anatomical structures were measured.

Methods: The studied material was collected from Arslanköy, Mersin. The collected specimens were identified. Dried specimens were kept in Istanbul University Faculty of Pharmacy Herbarium (ISTE) and filed using the ISTE number system (ISTE 98173). Also, some plant materials were kept in $70 \%$ ethanol for anatomical examination. All sections from plants were cut by hand using a blade. Samples were examined in SARTUR reagent. Photographs were taken using a light microscope.

Results: When we examined the cells around the stomata in the light of the neighboring cells, we observed that the stomata is an anomocytic type in leaf superficial section. The number of cells that radially surround the bottom of the trichomes on the leaf surface is 9 . This can be specified as a characteristic feature of this type. In the stem cross-section of $H$. kotschyanum species, secretory canals were observed. In $\mathrm{H}$. kotschyanum stem cross-section, irregular ridges were present and wing structure was not observed. The existence of secretory canals was observed in $H$. kotschyanum root cross-section.

Conclusion: We examined Hypericum kotschyanum anatomically for the first time. Therefore, this study is important in providing information that will be the source of other studies on this plant.
\end{abstract}

Keywords: Hypericum kotschyanum, plant anatomy, Turkey

\section{INTRODUCTION}

Hypericum L. genus is spreading all over the world and includes 460 species of trees, shrubs, and herbaceous plants (Perrone et al., 2013b). Approximately 100 species grow naturally in Turkey, of which 46 are endemic (Davis et al., 1967; Özhatay et al., 2009; Özhatay et al., 2011; Özhatay et al., 2015; Güner et al., 2000; Güner, 2012).

The secretory structures of the genus Hypericum are highly specialized for the synthesis and deposition of biologically active compounds and it has great potential. These secretory structures are found in vegetative and generative organs. Their phytochemical diversity has been revealed by taxonomic and anatomical studies (Perrone et al., 2013a; Ciccarelli et al., 2001; Nahrstedt, 1997).

Other studies worldwide have also concentrated on Hypericum perforatum $L$ which has traditionally been used to heal wounds, burns, and swellings, and also used as an anti-inflammatory. In addition, it has been used internally for stomach diseases, ulcers, enteritis, and diabetes (Özkan \& Mat, 2013). Moench's study on extracts of Hypericum species such as H. perforatum, H. calycinum L., and H. confertum Moench demonstrates that especially H. calycinum extracts are potential agents to use in cosmeceuticals for anti-aging and skin-whitening purposes (Ersoy et al., 2019). Experimental studies on the inhibition of the inflammatory pathway 
and recovery of DNA damage for $\mathrm{H}$. olympicum L. species have also been carried out. (Kurt-Celep et al., 2020).

There are some features which are characteristic of the anatomy of Hypericum. According to Metcalfe et al. (1957) pith rays are uniseriate, and the xylem and phloem are somewhat narrower. Pith development is greater in herbaceous Hypericum. Also, stomata of Hypericum species are generally surrounded by three or more cells.

Another characteristic feature of the anatomy of Hypericum is secretory canals' distribution. Secretory canals are always present in the secondary phloem, however sometimes there are also found in the pith, pericycle, and outer part of the primary cortex. In the root, secretory canals are present in the pericycle and secondary phloem of Hypericum (Metcalfe et al., 1957).

H. kotschyanum is an endemic species that was recorded as growing naturally only in Konya and Niğde provinces (Davis et al., 1967). The stem is $10-30 \mathrm{~cm}$ long, branched from the base, and has woolly hairs. Leaves are on the main stem, 5-15 mm, hairy. Inflorescence shapes are pyramidal or cylindric. There are glands like black dots on the petals. They usually grow on calcareous and rocky lands at an altitude of 1800-2000 m (Duman \& Sevimli, 2008).

H. kotschyanum is known to local people by its vernacular name "Kantaron, Antoron, Antoryon" in Arslanköy, Mersin province. Anatomical studies were not found in the literature review of the $H$. kotschyanum. In this study, the stem, leaf, and root parts of the endemic species were examined and the anatomical structure was revealed for the first time.

\section{MATERIAL AND METHODS}

The studied material was collected from Arslanköy, Mersin, by Prof. Dr. Şükran Kültür in June 2012. The collected specimens were identified by Şükran Kültür. Dried specimens were kept and filed using an ISTE number (ISTE 98173) in Istanbul University Faculty of Pharmacy Herbarium (ISTE). Some plant materials were stored in $70 \%$ ethanol for anatomical examination. All sections from the plants were cut by hand using a blade. Samples were examined in SARTUR reagent. Photographs were taken using a light microscope (Olympus BH-2 and Canon A640 digital camera).

\section{RESULTS}

\section{Leaf}

On the cross-section of the leaf, there is a thick cuticle layer on the outer surface. Trichome derived from epidermis are found on the lower and upper surface of the leaf. Below the cuticle layer, there is a single-layer epidermal. In the leaf mesophyll cross-section, palisade parenchyma cells are located under the upper epidermis and there are spongy parenchyma cells under this parenchyma layer. The mesophyll is bifacial. Also, schizogenous secretory canals with a large gap are distinguished (Figure 1). These gaps are 0,575 $\pm 0,159 \mu \mathrm{m}$ in diameter. The leaf thickness is between 1,483-2,287 $\mu \mathrm{m}$ and the average is $1,883 \pm 0,317 \mu \mathrm{m}$.

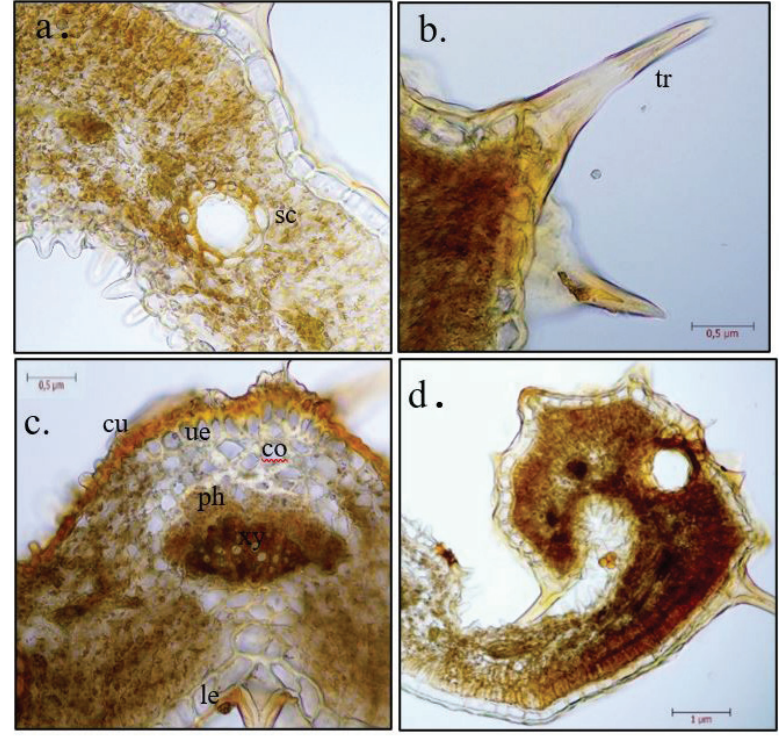

Figure 1. The cross-sections of leaf of H. kotschyanum ; (a) sc: secretory canal, (b) tr: trichome, (c) ue: upper epidermis, le: lower epidermis, cu: cuticle, co: collenchyma, ph: phloem, xy: xylem, (d) mesophyll general view.

In the cross-section of the main vein, 3-4 layers of collenchyma are observed under the upper epidermis. Xylem is on the lower side of the main vein and phloem is located on the upper; the veins are collateral (Figure 1). The leaf's main vein thickness average is $3,47 \mu \mathrm{m}$.

When the superficial cross-section of the leaf was examined, it was observed that the cover hairs were derived from the middle of 9 epidermal cells. Stoma was found only on the lower surface of the leaf. The leaf is hypostomatic. Stomata are the anomocytic type, but 3-5 cells are adjacent to the stoma (Figure 2). The stomatal index for the lower surface is 25 .
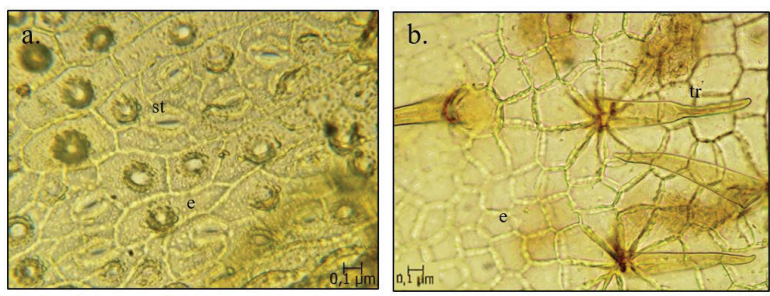

Figure 2. The surface sections of the leaf of H. kotschyanum; (a) lower surface of the leaf (b) the upper surface of the leaf; e: epidermis, st: stomata, tr: trichome.

\section{Stem}

In the cross-section of the stem, there is one epidermal layer under the thick-walled cuticle. There are many one-celled eglandular trichomes on the epidermal layer. Under this epidermal layer, collenchyma cells are located as 7-8 layers (Figure 3). The phloem layer extends under the collenchyma cells and the width of the phloem layer is about 0,639 $\pm 0,073 \mu \mathrm{m}$. Also, large secretory canals are observed on the phloem layer. Between the phloem and xylem layer, there is a thin cambium layer. The xylem has gaps that expand towards the pith. The pith is composed of parenchymatic cells that vary in diameter (Table 1). 

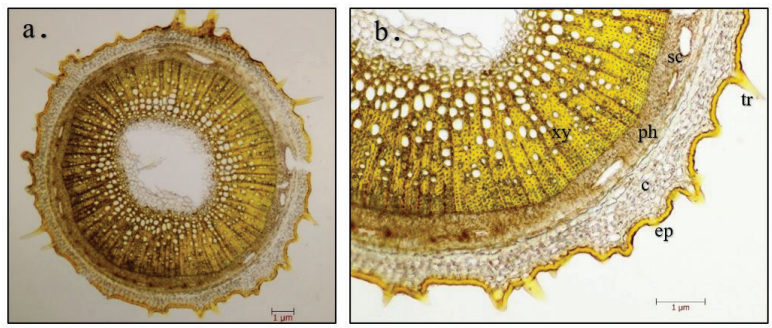

Figure 3. The cross-sections of the stem of H. kotschyanum; (a) general view, (b) cortex and vascular bundles; ep: epidermis, c: cortex, sc: secretory canal, fl: phloem, tr: trichomes, $x y$ : xylem.

Table 1. Anatomical measurements of H.kotschyanum.

\begin{tabular}{|c|c|c|c|}
\hline & \multicolumn{2}{|c|}{ Width $(\mu \mathrm{m})$} & \multirow{2}{*}{ Number } \\
\hline & Min.-Max. & Avr. $\pm S d$ & \\
\hline \multicolumn{4}{|l|}{ Stem } \\
\hline $\begin{array}{l}\text { Pith cell } \\
\text { (diameter) }\end{array}$ & 0,143-0332 & $0,203 \pm 0,056$ & \\
\hline $\begin{array}{l}\text { Trachea } \\
\text { (diameter) }\end{array}$ & $0,158-0,311$ & $0,232 \pm 0,044$ & \\
\hline Floem layer & $0,552-0,751$ & $0,639 \pm 0,073$ & \\
\hline \multicolumn{4}{|l|}{ Leaf } \\
\hline $\begin{array}{l}\text { Secretory } \\
\text { pockets } \\
\text { (diameter) }\end{array}$ & $0,462-0,687$ & $0,575 \pm 0,159$ & \\
\hline $\begin{array}{l}\text { Lower } \\
\text { stomata }\end{array}$ & & & 8 \\
\hline $\begin{array}{l}\text { Lower } \\
\text { epidermis } \\
\text { cell }\end{array}$ & & & 32 \\
\hline $\begin{array}{l}\text { Stomatal } \\
\text { index }\end{array}$ & & & 25 \\
\hline $\begin{array}{l}\text { Mesophyll } \\
\text { thickness }\end{array}$ & $1,483-2,287$ & $1,883 \pm 0,317$ & \\
\hline \multicolumn{4}{|l|}{ Root } \\
\hline $\begin{array}{l}\text { Cortex } \\
\text { thickness }\end{array}$ & $1,299-1,501$ & $1,395 \pm 0,063$ & \\
\hline $\begin{array}{l}\text { Phloem } \\
\text { thickness }\end{array}$ & $0,328-0,542$ & $0,443 \pm 0,075$ & \\
\hline $\begin{array}{l}\text { Trachea } \\
\text { (diameter) }\end{array}$ & $0,165-0,269$ & $0,202 \pm 0,034$ & \\
\hline
\end{tabular}

\section{Root}

In the cross-section of the root, there are 4-5 layers of periderm on the outside. Just below this layer, there is cortex tissue with a large number of secretory canals (Figure 4). Cortex tissue thickness is 1,395 $\pm 0,063 \mu \mathrm{m}$. The phloem layer is located outside the xylem and the average thickness is of this tissue is about 0,443 $\pm 0,075 \mu \mathrm{m}$. Xylem tissue is located in the innermost layer. There is a large width of traches. These traches are about 0,202 $\pm 0,034 \mu \mathrm{m}$ in width. The pith layer has parencymatic cells.
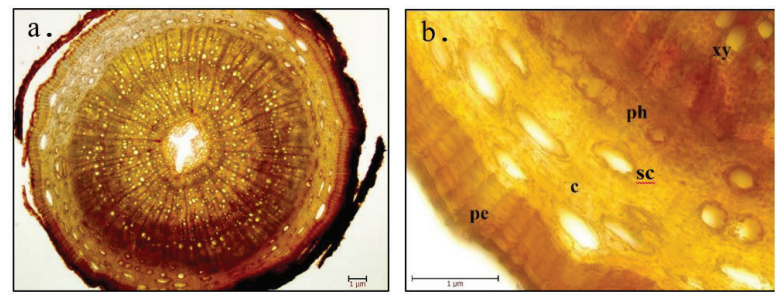

Figure 4. The cross-sections of root of $\mathrm{H}$. kotschyanum; (a) general view, (b) cortex and vascular bundles; pe: periderm, c: cortex, sc: secretory canal, ph: phloem, $\mathbf{x y : x y l e m . ~}$

\section{DISCUSSION}

The stem, leaf, and root anatomy of $H$. kotschyanum were examined for the first time with this study.

When we examined the stomata according to its neighboring cells, we observed that the stomata is an anomocytic type in the superficial section of the leaf. These observations on the Hypericaceae family properties correspond to other studies (Metcalfe \& Chalk, 1957). In studies carried out by Tekin (2017) and Altınbaşak (2019) the leaves of H. thymopsis Boiss. are bifacial, without hypodermis and stomata are anisocytic and anomocyctic. In our study we observed that $H$. kotschyanum stomata are anomocytic and the leaves are bifacial. Also H. perforatum, $H$. perfoliatum L., $H$. tetrapterum Fr., $H$. androsaemum L., and $H$. hircinum L., leaves are bifacial but the leaves of $H$. pubescens Boiss., $H$. triquetrifolium Turra, and $H$. aegypticum L. are isobilateral (Perrone et al., 2013a). Yaylacı et al. (2013) studied the anatomical characteristics of H. sechmenii Ocak \& Koyuncu. Study showed that $H$. sechmenii has equifacial leaves, anomocytic stomata.

The thick cuticle layer and stomata on the leaf only on the lower surface indicate that the plant grows in an environment that requires the use of water more efficiently. Hence, the features of this species confirm that $H$. kotschyanum has a xeromorphic structure.

Ciccarelli et al. (2001) stated in their study that there is a translucent secretion canal in the leaf of Hypericum perforatum Secretion canals of the same type were observed in the H. kotschyanum mesophyll layer. Also in the studies of Tekin (2017) and Altınbaşak (2019), H. scabrum L. and H. thymopsis have the same secretion canals. But H. spectabile Boiss does not have these features. The number of the cells that radially surround the bottom of the trichomes on the leaf surface is 9 . This can be specified as a characteristic feature of $H$. kotschyanum.

In the stem cross-section of $H$. kotschyanum, secretory canals were observed just like in the H. perforatum species in Lotocka \& Osińska's (2010) studies. In the study by Altınbaşak (2019) H. spectabile has large secretion canals in the phloem layer like H. kotschyanum. As in other studies with Hypericum species, collenchyma tissue was observed in the stem cross-section (Erkara \& Tokur, 2004; Lotocka \& Osińska, 2010). The presence of wings on the stem is an important feature for Hypericum species. Perrone et al. (2013a), Altınbaşak (2019), and Tekin (2017) showed the presence of wings in the species in their 
studies and used these structures in the differentiation of species. However, in $\mathrm{H}$. kotschyanum stem cross-section, irregular ridges are present and wing structure is not observed.

In the studies by Erkara \& Tokur (2004) and Altınbaşak (2019), it was stated that there are 4-5 rows of periderm layers in the roots of $H$. montbretii Spach, $H$. origanifolium Willd., H. spectabile and $H$. perforatum species. Also, $H$. kotschyanum has the same number of periderm layers in the roots. In the study conducted on H. montbretii, H. origanifolium, and H. perforatum species, the existence of secretion canals in the roots are not mentioned (Erkara \& Tokur, 2004). Unlike these species, the existence of secretory canals was observed in $H$. kotschyanum root crosssection.

We examined Hypericum kotschyanum anatomically for the first time. Therefore, this study is important in providing information that will be the source of other studies on the plant. Anatomical studies on the genus Hypericum can be used to distinguish the species more prominently.

Peer-review: Externally peer-reviewed.

Author Contributions: Conception/Design of Study- O.A., G.E.G., S..K.; Data Acquisition- O.A., G.E.G., Ş.K.; Data Analysis/Interpretation- O.A., G.E.G., Ş.K.; Drafting Manuscript- O.A., G.E.G., Ş.K.; Critical Revision of Manuscript- O.A., G.E.G., Ş.K.; Final Approval and Accountability- O.A., G.E.G., S.K

Conflict of Interest: The authors have no conflict of interest to declare.

Financial Disclosure: Authors declared no financial support.

\section{REFERENCES}

- Altınbaşak, O. (2019). Pharmaceutical Botany Research On Some Natural Spreading Hypericum L. Species In Turkey. (Master dissertation). Retrieved from https://tez.yok.gov.tr/UlusalTezMerkezi/ tezSorguSonucYeni.jsp.

- $\quad$ Ciccarelli, D., Andreucci, A. C., \& Pagni, A. M. (2001). Translucent glands and secretory canals in Hypericum perforatum L. (Hypericaceae): Morphological, anatomical and histochemical studies during the course of ontogenesis. Annals of Botany, 88(4), 637644. https://doi.org/10.1006/anbo.2001.1514

- Davis, P., Cullen, J., \& Codde, M. J. E. (Eds.). (1967). Flora of Turkey and the East Aegean Islands Vol. 2. Edinburgh: Edinburgh University Press.

- $\quad$ Duman, R., \& Sevimli, A. (2008). H. perforatum L., H. scabrum L. ve H. kotschyanum Boiss. Ekstrelerinin Antibakteriyel Aktivitelerinin Belirlenmesi. [Determination of Antibacterial Activities H. perforatum L., H. scabrum L. and H. kotschyanum Boiss. Extracts]. Selçuk Üniversitesi Fen Edebiyat Fakültesi Dergisi, 31, 27-33.

- Ersoy, E., Eroglu Ozkan, E., Boga, M., Yilmaz, M. A., \& Mat, A. (2019). Anti-aging potential and anti-tyrosinase activity of three $\mathrm{Hy}$ pericum species with focus on phytochemical composition by LC-MS/MS. Industrial Crops and Products, 141 (August). https://doi. org/10.1016/j.indcrop.2019.111735
Güner, A., Özhatay, N., Ekim, T., \& Başer, K. (Eds.). (2000). Flora of Turkey and the East Aegean Islands. Vol. 11 (Supplement II). Edinburgh: Edinburgh University Press.

- Güner, A. (Eds.). (2012). Türkiye Bitkileri Listesi-Damarlı Bitkiler. [Turkey Plants List-Vascular Plants]. İstanbul: Nezahat Gökyiğit Botanik Bahçesi.

- $\quad$ Kurt-Celep, I., Celep, E., Akyüz, S., Inan, Y., Barak, T. H., Akaydın, G., Yesilada, E. (2020). Hypericum olympicum L. recovers DNA damage and prevents MMP-9 activation induced by UVB in human dermal fibroblasts. Journal of Ethnopharmacology, 246(August). https://doi.org/10.1016/j.jep.2019.112202

- Lotocka, B., \& Osińska, E., (2010). Shoot anatomy and secretory structures in Hypericum species (Hypericaceae). Botanical Journal of the Linnean Society, 163(1), 70-86. https://doi.org/10.1111/ j.1095-8339.2010.01046.x

- Metcalfe, C. R., \& Chalk, L. (1957). Anatomy of the Dicotyledons Volume 1. London: Oxford University Press.

- Nahrstedt, A. (1997). Biologically active and other chemical constituents of the herb of Hypericum perforation L. Pharmacopsychiatry, 30(SUPPL. 2), 129-134. https://doi.org/10.1055/s-2007979533

- Özhatay, F. N., Kültür, Ş., \& Gürdal, M. B. (2011). Check-list of additional taxa to the supplement Flora of Turkey V. [ Turkish Journal of Botany, 35(5), 589-624. https://doi.org/10.3906/bot-1101-20

Özhatay, N., Kültür, Ş., \& Aslan, S. (2009). Check-list of additional taxa to the Supplement Flora of Turkey IV. Turkish Journal of Botany, 33(3), 191-226. https://doi.org/10.3906/bot-0805-12

Özhatay, N., Kültür, Ş., \& Gürdal, B. (2015). Check-list of additional Taxa to the supplement flora of Turkey VII. Journal of Pharmacy of Istanbul University, 45(1), 61-86. https://doi.org/10.5152/istanbuljpharm.2017.006

- $\quad$ Özkan, E. E., \& Mat, A. (2013). An overview on Hypericum species of Turkey. Journal of Pharmacognosy and Phytotherapy, 5(3), 38-46. https://doi.org/10.5897/JPP2013.0260

- Perrone, R., De Rosa, P., De Castro, O., \& Colombo, P. (2013a). A further analysis of secretory structures of some taxa belonging to the genus Hypericum (Clusiaceae) in relation to the leaf vascular pattern. Turkish Journal of Botany, 37(5), 847-858. https://doi. org/10.3906/bot-1206-22

- $\quad$ Perrone, R., De Rosa, P., De Castro, O., \& Colombo, P. (2013b). Leaf and stem anatomy in eight Hypericum species (Clusiaceae). Acta Botanica Croatica, 72(2), 269-286. https://doi.org/10.2478/botcro-2013-0008

- Potoğlu Erkara, I., Tokur, S. (2004). Morphological and anatomical investigations on some Hypericum L., species growing naturally in and around Eskisehir. Trakya Univ J Sci, 5, 97-105.

- Tekin, M. (2017). Pharmacobotanical study of Hypericum thymopsis. Revista Brasileira de Farmacognosia, 27, 143-152

Yaylacı, Ö. K., Özgis, I, K., Sezer, O., Orhanoğlu, G., Öztürk, D., Koyun$\mathrm{cu}, \mathrm{O}$. (2013). Anatomical studies and conservation status of rare endemic Hypericum sechmenii Ocak \& Koyuncu (Sect: Adenosepalum) from Eskişehir-Turkey. J. Selçuk Univ Nat Appl Sci, 2, 1-11. 